Habib Borjian* and Daniel Kaufman

\title{
Juhuri: From the Caucasus to New York City
}

DOI 10.1515/ijsl-2015-0035

Abstract: Juhuri is a dialect of the Tat language of the eastern Caucasus (specifically, Dagestan and Azerbaijan). Although Juhuri is dialectologically related to Persian, it is not mutually intelligible with any Persian dialect. The Juhuri speakers, called Mountain Jews, are estimated at around 200,000, most of whom have immigrated to Israel and the United States. The New York community is largely centered in Brooklyn around the Kavkazi Jewish Congregation. The language is still spoken by those born in the Caucasus, and is maintained in some families and some spheres of daily life. Many of these Mountain Jews are multilingual in Juhuri, Russian, Azerbaijani, Hebrew, and English. In this article, we situate the language within the context of the New York expatriate community and explore the role of Juhuri in relation to ethno-religious identity, language attitude, and functional domains. The data reported on here are based on interviews and a written survey. We conclude that although the odds are heavily stacked against the survival of Juhuri, there may be a critical mass of language activists who can turn the tide. The fate of the language in the twenty-first century will likely be decided in the next two decades.

Keywords: Tat language, Iranian languages, heritage language, endangered language, multilingualism

\section{Introduction}

Studies of multilingualism in New York overwhelmingly focus on communities speaking major world languages such as Russian, Spanish, German, Italian, among others (e.g. García and Fishman 2002). The true linguistic diversity of New York, however, lies far less in the many national languages one can hear on almost every street corner but is rather in the community languages that lack official status. With possibly the highest concentration of languages anywhere in the world, New York will take on an unexpectedly important role in the future of languages that are threatened in their homeland. Depending on the attitudes and actions of these New York communities over the next several decades, the

*Corresponding author: Habib Borjian, Columbia University, USA, E-mail: hb146@columbia.edu Daniel Kaufman, Queens College, City University of New York, USA,

E-mail: Daniel.Kaufman@qc.cuny.edu 
city will either remain a unique linguistic greenhouse or become the world's largest linguistic graveyard (Turin 2012).

We focus here on one particular community, the Mountain Jews, or Juhuro, whose New York population may prove critical to the future of the language. The Juhuro are a Jewish community from the Caucasus who immigrated in large numbers to the United States and Israel in the 1980s and 90s. Juhuri expatriates now far outnumber those who remain in Azerbaijan and Dagestan, where they lived almost exclusively until the late twentieth century. Juhuri is occasionally cited as one of the few Jewish languages on a par with Yiddish in terms of its divergence from its non-Jewish counterpart, Muslim Tat. Regardless of whether this proves correct, Juhuri remains an understudied and endangered language whose future will largely play out in diaspora contexts such as New York.

In this article, following an introductory section on the language, we discuss the results of our written survey and a set of semi-structured interviews with community members. This article offers a thorough account of the language practices and attitudes of the New York Juhuri community, a critical ingredient in understanding the prospects of the language's survival in the twenty-first century.

\section{The Tat language}

Juhuri is an autonym for the better-known term Judeo-Tat, the language of the Mountain Jews of the eastern Caucasus. The historical domain of Judeo-Tat extends from the mountainous valleys of Dagestan (now a "republic" in the Russian Federation) southward to the plains and piedmonts of Shirvan, which at the present time forms the northern part of the Republic of Azerbaijan. ${ }^{1}$

Judeo-Tat is a dialect of the Caucasian Tat language group; the other dialects are spoken by Muslims of both Shiite and Sunni denomination and on a much smaller scale by a group of Christians that recently migrated to Armenia. The Tat language, also called Tati, ${ }^{2}$ belongs to the Southwest Iranian family but geographically is a distant outlier. The closest relative of Tat is unquestionably Persian and it is generally assumed that Tat branched off from Persian, but whether this happened before or after the standardization of Persian in the tenth

1 Arrān and Shervān (Shirvan) are the historical provinces that constitute the territory of the present Azerbaijan Republic, the current name of which was coined in 1919.

2 The Tat language is to be distinguished from the Tati dialects of northwestern Iran, which belong to Northwest Iranian family. 
to twelfth centuries is an open question (Grjunberg and Davidova 1982; Windfuhr 2006; Borjian 2015). Whatever the time of parting may have been, the isolation has been long enough for the Tat language to undergo such profound structural changes that it has become mutually unintelligible with any known variety of Persian. The changes in Tat are not only intra-linguistic but are also due to strong areal influences from the neighboring languages of Caucasian and Turkic stock, above all Azerbaijani Turkish. Another source of influence on Tat, especially on its vocabulary, is Persian, the lingua franca of the Persianate world. In the study of the Tat language and people it is important to recall that before its Russian annexation in the nineteenth century, the south Caucasus was administratively and culturally an integral part of Persia. ${ }^{3}$

Before mass emigration in recent decades, Mountain Jews lived in villages throughout the mountainous valleys of Dagestan, as well as in its southern port of Derbend, constituting a quarter of its population. Other urban centers with considerable numbers of Mountain Jews are Makhachkala, the capital of Dagestan, and Grozny and Nalchik in Northern Caucasus. The distribution of Mountain Jews extended south to the district of Quba in northeastern part of Azerbaijan Republic. To the south of Quba, in an area of roughly 2,000 square kilometers, is the stronghold of Muslim Tats, who often share their villages with Azerbaijani-speaking populations. A large group of Tats abides in the Apsheron Peninsula, east of Baku, the capital of Azerbaijan Republic. Baku itself has been home to a considerable number of Tat speakers, Muslim and Jewish alike (Grjunberg 1963: 5-8; Zand 1985; Clifton et al. 2005; Authier 2012).

The dialectal divisions within the Tat language group have been subject to debate. Miller (1929) believes that all dialectal distinctions correspond to geographic position roughly along a south-north axis. Grjunberg on the other hand correlates the linguistic differences to religious divisions; he argues that Judeo-Tat is a single language different from Muslim Tat, while the latter is perceptibly divided among the Sunni and Shiite speakers (Grjunberg 1963: 7-8; Grjunberg and

3 Former studies of the Tat language include A. L. Grjunberg's important volume Jazyk severoazerbajdžanskix tatov (1963), followed by several articles of his on the dialects spoken by Muslim Tats. Judeo-Tat was the subject of an early study by V. F. Miller at the turn of the nineteenth century. During the earlier Soviet decades (1920s to 1940s), Judeo-Tat gained official status in Dagestan, and was adapted to Latin and then Cyrillic alphabets, in which periodicals and textbooks were printed. An important manifest of this literary period was the grammar of N. A. Anisimov, written in Judeo-Tat (Grammatik zuhun tati, [1932]). More recent contributions have been dictionaries by Agarunovs (2010; Quba dialect) and Dadashev (2006), and a grammar based on the literary language by Gilles Authier (2012). John M. Clifton et al. (2005) conducted a sociolinguistic fieldwork in ten Tat settlements in the Republic of Azerbaijan, including Q1rmızı Qäsäbä, the stronghold of Judeo-Tat near the town of Quba. 
Davidova 1982). In our belief, these two vantage points are not necessarily contradictory if we consider the geographic distribution of the three religious groups: Jews in the north, Sunnis in the middle, and Shiites in the south. A recent sociolinguistic study by Clifton et al. (2005) has also shown that there is little evidence for a linguistic division along religious lines. Still, the importance of religious identity in self-designation is undeniable. Clifton et al. (2005) found the speakers of each variety saying that only members of the Muslim community speak Tat, while members of the Jewish community are Mountain Jews and speak Juhuri, not Tat. Members of both communities feel strongly that they speak different languages, and the sociolinguistic situations in the two groups are very different (Clifton 2009). We will return to the problem of identity in Section 4.

\section{Juhuri community in New York City}

Along with other Jews of the Soviet Union, Mountain Jews began to emigrate in the 1970s and 1980s, with a mass emigration taking place in 1990s, predominantly to Israel and North America. Immigration to the United States peaked in the mid-1990s and continued up to mid-2000s in the earnest. The largest JuhuriAmerican communities live in in New York City, Detroit, Baltimore, Cleveland, and Chicago. Their number in New York City is estimated to be above 20,000 (Abramov 2014).

The Juhuri-speaking community in New York is largely centered around Ocean Parkway in Brooklyn, with the Kavkazi Jewish Congregation in the Kensington neighborhood serving as its cultural and religious hub. This neighborhood is also home to large congregations of Syrian and other Mizrachi Jews as well as a sizable population of Russian speakers from various parts of the former Soviet Union. Most Mountain Jews work outside their community. Many men are occupied as laborers and technicians, and to a lesser extent, whitecollar professionals, working in both private and public sectors. Typical fields of employment for women include home health aide, secretarial work and nursing. Upon immigration to their new home country, some younger individuals sought two-year training programs to obtain skills for higher paying jobs. There are also those who run businesses, including restaurants, which play an essential role in gluing the Juhuri community together.

The community has a monthly newspaper Novyj rubezh [New frontier], which began in 2003 and reached its 126th issue in May 2014. The paper covers current issues, religious topics, historical themes, as well as profiles of prominent community members from New York, Israel and the Caucasus. Although printed and edited from New York, the publication is almost entirely in Russian 
with very occasional features in the Juhuri language (as well as Azerbaijani). Its monthly circulation of 3,000 issues is said to reach Moscow, Baku, Tel Aviv, and Toronto. A series of articles on the Juhuri language and orthography by Yakov Abramov and Rashbil Shamayev were published in recent issues.

A focal point of the Brooklyn community is the synagogue named Kavkazi Jewish Congregation in English and Beth Haknesseth Ohr Hamizrach [Light of the East] in Hebrew. In addition to the regular Saturday services, evening Hebrew classes are held regularly for the younger generation, and not less significantly community gatherings on Sundays. Having grown up in the Soviet Union, many Mountain Jews had never received formal religious education prior to immigration and many were almost completely disassociated from the Jewish religion. ${ }^{4}$ One can subsequently see a rebirth of religiosity, especially among the youth. In the absence of a qualified Juhuri rabbi in New York, two Ashkenazi rabbis, one originally from Russia and one from Brooklyn, lead the congregation. As a result, Russian and English are the languages of religious education within the synagogue, with English being used with the younger generation raised in New York City. The adoption of an Ashkenazi rabbi by a non-Ashkenazi congregation is highly unusual, even in New York, and speaks to the relative independence of the Juhuri community from Mizrahi and Sephardic centers of gravity. ${ }^{5}$ Although we did not have occasion to study the religious life of the community in any detail, it seems from casual observation that Juhuri folk traditions have largely given way to the "mainstream" orthodox practices of the rabbis leading the congregation. For instance, the traditional story telling that used to take place during Nisono/Passover are replaced by the various activities involved in the orthodox observance of the holiday.

Outside the religious framework, music and dance are a fundamental part of the community's culture. The Lezginka Dance Company, based in Brooklyn, preserves and continues community dance traditions through teaching and performance. Group dancing in traditional Caucasian costumes is an integral part of Kavkazi communal gatherings. The celebrations, even those held at the Kavkazi Congregation, involve traditional dancing of a competitive nature. ${ }^{6}$

4 One community member related to us how he had to leave Soviet Azerbaijan in the 1980s in order to have his son circumcised.

5 Alternatively, this could be due to the long-standing historical connections between the Juhuri and Ashkenazi communities in Eastern Europe. Bram (2013: 5) notes that Juhuri rabbis had been travelling to Lithuania, Poland, and Russia for religious studies since at least the nineteenth century. He also shows that Sephardic and Ashkenazi influences can be seen in the traditional Juhuri liturgy.

6 Bram (2013: 6-8) discusses the prominence of dance groups throughout Juhuri communities in Israel and efforts to reframe the dances as part of Jewish folklore. 
While the dancers of the Lezginka Dance Group are almost entirely Jewish, the dances themselves are associated with the Lezgian ethnic group, who are largely Muslim and inhabit the border area of southern Dagestan and northern Azerbaijan. The inclusion of such diverse cultural ingredients in the identity of the New York community is a direct reflection of the diversity found in the Juhuri homeland (Bram 2009), despite the fact that the Juhuri community is no longer in close contact with other Caucasian communities in Brooklyn. ${ }^{7}$

It should be noted that Beth Haknesseth Ohr Hamizrach also includes several non-Kavkazi members. There are Ashkenazi Jews from Dagestan or Azerbaijan who grew up among Mountain Jews and maintain a connection to the community. There are also a handful of Bukharian Jews from the neighborhood of the synagogue who attend due to the lack of a Bukharian congregation in Flatbush. With both groups, Russian is the lingua franca used for communication.

\section{Identity}

Oral traditions of the Mountain Jews claim that they are descendants of the Biblical Northern Lost Tribes who would have been exiled by the Assyrians in the eighth century BCE, after the destruction of Jerusalem's first temple, or in a later stage during the Babylonian exodus in 598 BCE. A common belief among the Mountain Jews is that their ancestors came to the Caucasus via Media, northeastern Iran (Anisimov 1888; Brook 2006; Bosworth 2014; Juhuro.com). This theory should be evaluated with caution on linguistic grounds, since the Southwest Iranian origin of Juhuri renders a short route from Mesopotamia to the Caucasus highly improbable.

The new community in New York City has been in search of a name for itself. There existed in the Soviet Union two designations for the Mountain Jews, who were given the narrow choice to register themselves as either Tats or Jews (Zand 1985). There is of course no such constriction in the United States, and the Mountain Jews are free to choose a name for their community. Among our interviewees, many see no problem with the autonym "Juhuri" to be used also as the exonym for their language, save the obscurity of the word to the general American public. The same problem holds for the term "Mountain Jews", which association is not readily recognizable to the gentile population. The same term in Russian, "Gorsky", is readily recognizable by Russian-Americans, hence widely used as an exonym of the New York City Juhuri community, which is tightly connected with other immigrants from the former Soviet Union. Kavkazi,

7 However, unlike the situation in Israel, there do exist connections on the individual level between Juhuri people and non-Jewish immigrants from the Caucasus in New York. 
an equivalent term to Gorsky, is as widely used, including on the synagogue's plaque "Kavkazi Jewish Congregation". We have seen the phrases "Proud to be a Gorsky Jew" and "Gorsky-Kavkazi Jews of New York" on the T-shirts and banners of the young participants in the annual Jewish parades. There seem to be a feeling among the community that the negative connotation of Gorsky and Kavkazi in Israel and Moscow, ${ }^{8}$ especially among the Ashkenazi Jews therein, is not as relevant in the United States, because here the Juhuri community is increasingly exposed to a much more diverse population than Russians and/or Jews. When we asked, why not, instead of "Kavkazi", its well-known English equivalent "Caucasian" would be used, we were told that it was indeed tried once in renaming of the synagogue, as "Caucasian Jewish Congregation", but raised concern among some neighborhood communities as being racially charged. All in all, the American-Juhuri community seems too young to have arrived at a single self-designation. Amidst the lack of consensus in self-designation, Juhuri children in school often identify themselves as Russian Jews or Azerbaijanis.

\section{Juhuri provenances and varieties}

The Mountain Jew immigrants in New York City consider their community as a single unit distinct from other Jews. The in-group divisions are much less important. The most general distinction, based on geographic provenance, patterns of emigration and family ties, is between Azerbaijani and Russian Juhuro, with roughly equal population in New York City. The latter are by and large from Dagestan, especially the town of Derbend, and to a lesser extent from Nalchik, the capital of Kabardo-Balkar republic in the Russian Federation. Those from Azerbaijan Republic may be divided into Qubais and Shirvanis; those from Baku originate from either of these regions.

The Qubais seemingly comprise the largest distinguishable type, twice as many as Shirvanis. Most Qubais have connections to the adjoining township of Q1rmızı Qäsäbä, which is exclusively populated by Mountain Jews, who were some 10,000 strong before the recent migrations (cf. Clifton et al. 2005). Having been isolated by mountains from both Dagestan and Shirvan, Qubais appear to be the most conservative group, hence the most active concerning preservation of the

8 For Juhuri relations vis-à-vis Russian Jews in Moscow, see Goluboff (2003); for Israel, see Littman (2010). 
Juhuri culture and language. Most parents who talk to their children in Juhuri are from Quba; they either came to the United States directly or via Israel - seldom from Baku or Derbend. Qubais believe that Shirvanis speak a "purer" form of Azerbaijani Turkish and have no objection in giving Azerbaijani names to their children (as against specifically Juhuri names), as such they are far more Azericized compared to Qubais. In a group interview, when we asked how would Qubais characterize the Dagestani Juhuro, there was no quick reply, but the interviewees took on our hint that Dagestanis are more Russified, more so the Juhuro of Nalchik, contrasting "Persian-ness" of the Azerbaijani Juhuro.

Our informants admitted that there were varieties of Juhuri spoken in New York City, but believed that the dialectal difference seldom hinders intelligibility on the part of the speakers. Younger people are in general unaware of Juhuri varieties. The Mountain Jews from various parts of Azerbaijan (Quba, Shirvan, and Baku) believe that they share very similar accents, while Dagestanis have a noticeably different dialect; an example is Qubai $o v$ versus Derbend ' $a v$ 'water'. Whatever the dialectal variations might be, it does not seem to be an issue for the Juhuri community of New York.

\section{Multilingualism}

Our linguistic fieldwork among the Mountain Jewish community of New York City spans over a year since the spring of 2013. We conducted several individual and group interviews in the synagogue, houses, outdoors, and restaurants. In order to reach various segments of the community in a systematic way, we also prepared a questionnaire in both English and Russian. Focusing on issues for which variation is likely among segments of the community, the questions aimed in particular at language use, multilingualism, proficiency, and language attitudes. The 24 respondents were equally divided between both sexes and homogeneously distributed among generations, ranging in age between 16 and 88 .

\subsection{Multilingual proficiency}

Multilingualism is the norm among the Mountain Jews of New York City. Five languages predominate: Juhuri, Russian, English, Azerbaijani, and Hebrew, with age as the primary function. The core languages, Juhuri and Russian, were identified as native tongues by most respondents to the questionnaire. The mother tongue was identified as Juhuri for most of the individuals above 50 years old, as Russian for those below 30, and as either or both languages for the generation in 
between. Interestingly, some individuals who were exposed only to Russian from their parents still had the chance to acquire Juhuri from the grandparents who cohabited or lived nearby. Azerbaijani and Hebrew come into play depending on the provenance of the family and migration routes from the Caucasus to the United States. Some individuals who grew up in Baku identified Azerbaijani, along with Juhuri, as their native tongue, inferring a middle class status of their family in Azerbaijan. Hebrew as a spoken language has relevance only to those families who stayed in Israel for a considerable period before remigration to the United States. No respondent identified English as his/her mother tongue.

In the questionnaire, we inquired about levels of proficiency (good, little, none) with reference to four language skills: understanding, speaking, reading, and writing. A schematic distribution of the first two skills with reference to age is given in Table 1 . The table pertains to the families who migrated directly from Azerbaijan and have been naturalized for an average of fifteen to twenty years. The scheme highlights Russian as the most enduring language across all age brackets, while Juhuri's gradual disappearing trails English learning, leaving little room for coexistence of Azerbaijani, which has lost its former merit as the fourth language. The parentheses indicate the precarious status of a language across generational boundaries. This table can easily be modified for other scenarios: (1) for families coming from Dagestan or elsewhere in Russia, the column pertaining to Azerbaijani should be dropped; (2) for those who stayed in Israel a Hebrew column should be added.

Table 1: Language proficiency relative to age among the later 1990s immigrants from Azerbaijan.

\begin{tabular}{lllll}
\hline $70+$ & $\mathrm{A}$ & $\mathrm{J}$ & $\mathrm{R}$ & \\
$50-70$ & $\mathrm{~A}$ & $\mathrm{~J}$ & $\mathrm{R}$ & $(\mathrm{E})$ \\
$30-50$ & $(\mathrm{~A})$ & $\mathrm{J}$ & $\mathrm{R}$ & $\mathrm{E}$ \\
$20-30$ & & $\mathrm{~J})$ & $\mathrm{R}$ & $\mathrm{E}$ \\
Teenagers & & & $(\mathrm{R})$ & $\mathrm{E}$ \\
\hline
\end{tabular}

Note: $\mathrm{A}=$ Azerbaijani, $\mathrm{J}=$ Juhuri, $\mathrm{R}=$ Russian, $\mathrm{E}=$ English.

A similar pattern surfaced for reading and writing skills. English is poorly known among the senior citizens, while Russian is well mastered across the board among those who were educated in Russia or Azerbaijan. For the latter a strong pattern was additional proficiency in Azerbaijani, except those who attended Russian schools in Baku. As for Hebrew, the respondents bifurcated. Most young males know some Hebrew, owing to extracurricular religious education or, in a few cases, Yeshiva. Of those who lived in Israel, some, but not all, knew how to read and write Hebrew. As regards Juhuri, reading and writing has limited 
applicability. Except one elder from the generation who received its primary education in Judeo-Tat, the rest recognize Juhuri as a spoken language. Younger respondents mostly had not seen the language in writing or were even unaware of literary Tat. There were also middle-aged individuals among the interviewees who could read Cyrillic Tat with relative ease despite its tricky orthography. They explained that they had some prior exposure to written literature in Baku.

\subsection{Language use by domain}

The language spectrum Juhuri - Russian - English correlates very well with the age continuum from old to young, in both inter- and intra-generational communication. The older people tend to speak with each other in both Juhuri and Russian with a great deal of code switching, and the role of Juhuri fades away with the presence of younger people. As a token of respect some youth effort to talk with elders in Juhuri. The role of English increases in the absence of seniors. Gender-wise, the spectrum of the language triad inclines towards its English end for the female speakers. This is probably because women are in closer contact with children, rather than because of the greater conformity women show towards social norms dictated by the present dominant linguistic setting. This issue deserves further investigation.

In the questionnaire and interviews we asked about the language use in various social and personal domains. The emerging pattern points to Russian dominance at home. Juhuri is used occasionally and English increasingly. There were parents who said they used Juhuri when they intended to keep the conversation private from children. Along with the trio, Hebrew and Azerbaijani occasionally appeared among the answers. In the synagogue the language follows the pattern stated in the previous paragraph. Sermons are given solely in Russian by the Russian rabbi. At family and communal gathering an assortment of languages is used with frequent code switching. The songs sang in such occasions are mostly in Juhuri. The question, "In which language are most of the songs you learned from your parents?” received both Russian and Juhuri as common answers, and Azerbaijani as less common. A surprising pattern was counting, which is done normally in Russian rather than in Juhuri. With respect to media, local Russian periodicals and broadcasting appear popular. The ubiquity of Russian in the Brooklyn neighborhood could explain why some younger members of the community are more familiar with Russian than Juhuri despite never having lived in a Russian speaking country. The other relevant factor, of course, is that their parents may have spoken Russian more than Juhuri even in Azerbaijan, especially if they were from Baku. One 48 year old woman from Baku whom we interviewed informally reported that, as a child, her parents spoke to her in 
Russian while her grandparents spoke to her in Juhuri, a pattern which was probably already common during the 1960s. ${ }^{9}$

\subsection{Language attitudes}

The feelings expressed by various segment of the community about the choice of language may be characterized as adaptive in general. Most interviewees expressed little objection against loss of Juhuri to the dominant languages of various countries they have ended up living in. They also show great flexibility in accepting the use of several languages in various circumstances or even simultaneously at communal gatherings.

Most informants believed that it is good or important to speak in Juhuri, for the reason that Juhuri is their ancestral language which helps strengthening family ties, or it is basic to Juhuri culture and identity. ${ }^{10}$ The question, "Which of these most makes you Juhuri", was answered with "Juhuri traditions" by $60 \%$ of the respondents, "Juhuri language" by $25 \%$, and "being Jewish from the Caucasus" by $15 \%$. We also found a consensus across generations that it would be nice to be able to read and write Juhuri.

Nevertheless, the prestige of Juhuri seems not to be very high within the community. The second generation's replies were ambivalent when asked if they are proud of the Juhuri language. Moreover, neither the immigrants nor the older first generation Americans show serious interest in teaching Juhuri to their children. While some members of the younger generation express interest in the language, they have not thought about learning the language seriously and admit that the impracticality of the language or difficulty in learning it might impede them pursuing it. ${ }^{11}$ This can be compared with Bram's (2008) discussion of language attitudes among the Juhuro in Israel, where they “... learned to think about their language as something belonging not only to the past, but to a completely different and even inferior cultural sphere" (Bram 2008: 345). While

9 Cf. Bram (2008: 338-339).

10 In one of our interviews, a female college student responded that it was the connections to Iranian Jews and the Persian speaking world that made it important to preserve the language. Other interviewees also referred to Juhuri as a form of "Farsi" but while the community seems to be widely aware of their Iranian origins, we did not find the student's sentiments echoed by any of the other respondents.

11 Kazakevich and Kibrik (2007: 246-247) report on a 1990s survey indicating contradictions in positive attitudes and actual practice among Siberian populations. While the idea of passing the language on was highly valued, in actuality, Russian was the language used with children. Such divergences in attitude and practice may in fact be the norm rather than the exception. 
we did not encounter any overtly negative attitudes towards Juhuri in our study, the fact remains that even in America, members of the older generation who are not comfortable with speaking English prefer Russian or Hebrew (if they passed through Israel) over Juhuri in communicating with children.

\section{Language vitality: Will Juhuri survive?}

Our findings point to a dire situation for the viability of Juhuri. The predominant language of the community is Russian and increasingly English. While members of the immigrant generation speak Juhuri with each other, they seem to regularly speak Russian as well. With the exception of music, Juhuri is losing all its domains under pressure from the larger languages, Russian and English. In New York, Juhuri has few young good speakers, notwithstanding an ambivalent interest in the language. It appears that the language, which thrived in rural isolation of the Caucasus, has retained few of its historical functions in the new urban settings in which the Mountain Jews now live. This observation is in agreement with those made by other researchers (Zand 1972; Shapira 2007; Clifton et al. 2005; Littman 2010; Bram 2008), as well as by UNESCO (2014), which lists Juhuri in both the Caucasus and Israel as a "definitely endangered" language.

In Juhuri media outlets, the Juhuri language plays only a symbolic role, if it makes any appearance at all. Juhuri media in Israel is in Hebrew and Russian, media from Azerbaijan is in Azerbaijani, and that from America and Russia employs Russian almost exclusively. In many of the television programs and publications, there are short segments dedicated to teaching bits and pieces of the language. STMEGI (International Charitable Fund of the Juhuri), by far the largest Juhuri media outlet with its own television station and publication in Russia, dedicates a few minutes in its programming to teach basic phrases through the medium of Russian. Despite this total dearth of actual Juhuri in community media, there are numerous proclamations about the language's importance and even its vitality. A recent article on the website of Tovushi, a youth-oriented Russian language publication of the New York Juhuri community, stated, "Language lives forever, and I think that our language will live and even be the language in which we socialize our children. Juhuri is a unique language and is the main content of our being."12 The same article decries the

12 “Язык живет вечно, и я думаю, что наш язык будет жить, несмотря даже на тот язык, в котором живут и общаются наши дети. Уникальность языка джуури - вот главное содержание нашего бытия.” 
pessimism surrounding the language's future: "Linguistic scholars of European origin for some reason decided that the Juhuri language is dying. It has been living for centuries and will continue to live." While there seems to be a disconnect between statements such as the above and the facts on the ground, revitalization of Juhuri is not an entirely hopeless proposition. Now, for the first time after nearly a quarter century of settlement in New York, concerns are being expressed regarding the language's vitality. The New York based newspaper, Novyj rubezh, has recently launched a page in Juhuri, as well as the series (in Russian) "What we know about the language of the Mountain Jews" (by Yakov Abramov), aiming at preservation of the language.

The idea of winning back Juhuri its former literary status in the Soviet Union is central in the language planning discussions. It is thus unsurprising that the topic of orthography plays an outsize role in discourse on the language's future. Yakov Abramov, a New York based author and organizer, believes that the former Cyrillic alphabet is a burden for the community living in the United States and Israel. The use of Hebrew script is discouraged for its ambiguities, but probably equally because the revitalization of Juhuri is a secular endeavor rather than a religious one. ${ }^{13}$ To make progress on this and other linguistic issues, a conference is being planned in Baku by the members of the New York community. Asking why Baku, when the Juhuri demographics show a sharp decline in Azerbaijan, we were told that the city is still geographically central to the dispersed Juhuri immigrants and that some of the most knowledgeable scholars of the language work in the Science Academy of Azerbaijan. We also noticed that the organizing committee of the conference is dominated by those from Baku rather than Dagestan. The project is supported by STMEGI, which is also funding an online library project that would bring together all materials published in the language. As is typical of similar community based efforts, the focus is on the written language with little attention being paid to the critical work of reclaiming domains of language use for Juhuri. Still, these efforts offer a measure of promise. Whether this push will remain within a small circle of intellectuals and activists or spread to larger segments of the community is yet too early to say. The ambivalence is echoed in the equal split between the negative and the affirmative replies of the respondents to our survey question: "Do you think Juhuri will survive in generations to come?"

It is instructive to compare the situation of Juhuri with that of the Bukharian Jews in regard to language. Bukharian by all measures should be better positioned both in Israel and New York. The community is more affluent, more numerous and their language, which is in a dialect relationship to Tajik and

13 In our experience, which is still far from comprehensive, those from the New York community who are most committed to Juhuri revitalization have limited familiarity with Hebrew. 
Persian, is far better recognized. Furthermore, the community was not subject to the same degree of linguistic manipulation as the Juhuri community was at the hands of the Soviets and Israel. ${ }^{14}$ Yet it cannot be said that Bukharian is faring much better than Juhuri in terms of its transmission. The Bukharian community of New York has a number of poets and singers and has made efforts to teach the language in at least one synagogue but Russian and English are by far the dominant languages among those under age 40. Print materials and formal communications are completely in Russian. In a conference of roughly 200 people held at the central Bukharian synagogue in the Forest Hills neighborhood of Queens, New York, all presentations were made in Russian rather than Bukharian, despite the fact that the vast majority of the audience were Bukharian speakers. Bukharian language use among the younger members of the community who grew up in New York is near zero, as is the case with their Juhuri counterparts. This suggests that the rapid language attrition we see among the Juhuri cannot be completely attributed to their hardships following immigration or their relatively small numbers. Rather, it appears as a typical outcome for minority languages of the former Soviet Union whose decline began far before their immigration to other lands. ${ }^{15}$

Acknowledgements: The research reported on here was carried out under the auspices of Endangered Language Alliance. We would like to also thank Yakov Abramov, Robert Avishalom, Ross Perlin, Kevin Kwong, Michael Lebovitz, and Rebecca Friedman, who assisted us in our fieldwork.

\section{References}

Abramov, Yakov. 2014. Što my znaem o jazyke gorskix evreev [What do we know about the language of the Mountain Jews?]. Novyj rubež, no. 125, April, p. 4.

Agarunov, Jakov M. \& Mixail Ja. Agarunov. 2010. Bol'šoj slovar' jazyka gorskyx evreev džuuri = Kala lyqat zuhun çuhuri. Baku: Abilov, Zejnalov i synov'ja.

Anisimov ISh. 1888. Kavkazskie evrei-gortsy (Caucasian Jewish mountaineers). Moscow: Typography of E.G. Potapov.

Anisimov, N. A. 1932. Grammatik zuhun tati, Moscow: Centrizdat (Centralnoe izdatel'novo narodov SSSR).

14 As Bram (2008) discusses in detail, the Juhuri community in Israel were subject to two misclassifications. First, at the hands of the Soviets who sought to sever their ties to other Jewish groups and second, at the hands of the Israelis, who lumped them together with other immigrants from the former Soviet Union as Russian speakers.

15 Indeed, Kazakevich and Kibrik (2007) report as much in their recent survey article on the vitality of the languages of the former Soviet Union. 
Authier, Gilles. 2012. Grammaire juhuri, ou judéo-tat, langue iranienne des Juifs du Caucase de l'est. Wiesbaden: Ludwig Reichert.

Borjian, H. 2015. Judeo-Iranian Languages. In A. Rubin \& K. Kahn (eds.), Handbook of Jewish languages, 234-295. Forthcoming 2015.

Bosworth, C. E. 2014. "Tat, 1. Historical development of the term." In Encyclopaedia of Islam, Second Edition. Brill Online, 2014. http://referenceworks.brillonline.com/entries/encyclo paedia-of-islam-2/tat-COM_1197 (accessed 17 June 2014).

Bram, Chen. 2008. The language of Caucasus Jews: Language preservation and sociolinguistic dilemmas before and after the migration to Israel. Irano-Judaica 6. 337-351.

Bram, Chen. 2009. Caucasus Jews and their Neighbors: Social Network in a Multi-Ethnic Society. In Ergun Ozgur (ed.), The North Caucasus, histories, diasporas and current challenges, 22-35. New York: Social Sciences Research Council.

Bram, Chen. 2013. Cultural identity and intercultural creation among the Jews of the Caucasus. In Havivah Pedaya (ed.), The Piyyut as a cultural prism. 324-341. Jerusalem: Van Leer Jerusalem Institute and Hakibbutz Hameuchad.

Brook, K. A. 2006. The Jews of Khazaria. Maryland: Rowman \& Littlefield.

Clifton, John M. 2009. “Do the Talysh and [Muslim] Tat Languages Have a Future in Azerbaijan?” Work Papers of the Summer Institute of Linguistics, University of North Dakota Session, vol. 49, at http://arts-sciences.und.edu/summer-institute-of-linguistics/work-papers/_ files/docs/2009-clifton.pdf (accessed 17 June 2014).

Clifton, John M., Gabriela Deckinga, Laura Lucht \& Calvin Tiessen. 2005. Sociolinguistic situation of the Tat and Mountain Jews in Azerbaijan. SIL International.

Dadashev, Mixail. 2006. Russko-tatskij (gorsko-evrejskij) slovar' = Gofnome az urusi ə juhuri. Moscow: Sobranie.

García, Ofelia \& Joshua A. Fishman. 2002. The Multilingual Apple: Languages in New York City. Berlin: Mouton de Gruyter.

Goluboff, Sasha L. 2003. Jewish Russians: Upheavals in a Moscow Synagogue. Philadelphia: University of Pennsylvania Press.

Grjunberg, A. L. 1963. Jazyk severoazerbajdžanskix Tatov. Leningrad: Science Academy.

Grjunberg, A. L. \& L. X. Davidova. 1982. Tatskij jazyk. In V. S. Rastorgueva (ed.), Osnovy iranskogo jazykoznanija III.1. Novoiranskie jazyki: Zzapadnaja gruppa, prikaspijskie jazyki, 231-286. Moscow: Science Academy.

Kazakevich, Olga \& Aleksander Kibrik. 2007. Language endangerment in the CIS. In M. Brenzinger (ed.), Language diversity endangered, 233-262. Berlin \& New York: Mouton de Gruyter.

Littman, Shany. 2010. Saving another dying Jewish language before it's too late: Juhurispeaking descendants of Mountain Jews from the Eastern Caucasus are documenting and preserving the rich legacy of their language. Haaretz, 19 April. http://www.haaretz.com/ weekend/week-s-end/saving-another-dying-jewish-language-before-it-s-too-late-1.284542 (accessed 17 June 2014).

Miller, Boris V. 1929. Taty, ix rasselenie i govory [Tats, their location and dialects]. Baku.

Miller, Vsevoloda F. 1892. Materialy dlja izučenija evrejsko-tatskogo jazyka. Vvedenie, teksty $i$ slovar' [Materials for Study of the Judeo-Tat Language. Introduction, Texts, Glossary]. St. Petersburg: Academy of Science.

Shapira, Dan. 2007. Judeo-Tat. Encyclopaedia Judaica. Ed. Michael Berenbaum and Fred Skolnik. 2nd edn. Vol. 11. Detroit: Macmillan Reference USA. 560-561. Gale Virtual Reference Library. Web. 13 May 2014. 
Turin, Mark. 2012. New York, a graveyard for languages. BBC News Magazine. December 15, 2012, http://www.bbc.com/news/magazine-20716344.

UNESCO. 2014. UNESCO Atlas of the World's Languages in Danger, http://www.unesco.org/ culture/languages-atlas/index.php (accessed 31 October 2014).

Windfuhr, G. 2006. Language change and modeling modal axes: Irano-Turkic convergence. In L. Johanson \& C. Bulut (eds.), Turkic-Iranian contact areas: Historical and linguistic aspects, 252-282. Wiesbaden: Harrasowitz.

Zand, M. 1972. The Culture of the Mountain Jews of the Caucasus and the Culture of the Jews of Bukhara during the Soviet Period. In Jewish Culture in the Soviet Union. Proceedings of the symposium held by the Cultural Department of the World Jewish Congress, Jerusalem, January 30-31. 134-147.

Zand, M. 1985-1986. The literature of the mountain Jews of the Caucasus. Soviet Jewish Affairs, 15(2). 3-22; 16(1). 35-51. 